\title{
RIGHTS AND DUTIES OF DECLARANT ALIENS
}

\section{Maximilian Koessler $\dot{\dagger}$}

American naturalization law has been subject to many changes, both in its fundamentals and in its particulars, during the I 50 odd years which elapsed between its first being shaped by the Act of Congress of I790 and its recent codification in the Nationality Act of 1940. However, the peculiarly American practice of distinguishing a special category of declarant aliens, or in common parlance persons with "first papers", from other non-citizens was introduced by the Naturalization Act of I795; and it has since been retained on the statute books, being presently defined by Section 33I of the Nationality Act of 1940.

At variance with the law of most other countries, an individual who lawfully enters the United States may not, as a rule, apply at once for a certificate of citizenship, regardless of the length of his uninterrupted residence in this country. Having maintained residence for the statutory period and having satisfied certain other requirements, he must make a declaration of his intention to become a citizen. ${ }^{1}$ Furthermore, after the expiration of a minimum period, he must apply for "second papers"; and this application must be made within the period during which his declaration of intention remains valid. ${ }^{2}$

Ostensibly a certificate testifying to the fact that a person has solemnly voiced the desire to become an American citizen, "first papers" are more than the record of a unilateral declaration. The applicant must submit to an examination under oath before the clerk of a naturalization court or his deputy $;^{3}$ and his application may be denied because of the applicant's illegal entry, race, or other circumstance relevánt as a ground of exclusion. Consequently the "first papers" represent, in

$\dagger$ Jur. D., University of Austria in Czernowitz; A. M., I94I, Columbia University; former member of the Vienna bar; author of Enemy Alien Internment: with special reference to Great Britain and France (1942) 57 PoL. Scr. Q.' 98, and numerous articles in German and French legal periodicals.

I. But many categories of exemption from the declaration of intention are provided for in the Nationality Act of 1940: e. g., for former American citizens, for spouses of American citizens, for persons honorably discharged from service in the armed forces of the United States. 54 STAT. II45, II47, II49 (I940), 8 U. S. C. A. $\$ \$ 7 I 1,717,724$ (1942). The Second War Powers Act, signed by the President on April 2, 1942, added a further category covering "any person, not a citizen, regardless of age, who has served or hereafter serves honorably in the military or naval forces of the United States during the present war, and who, having been lawfully admitted to the United States, including the territories and possessions, shall have been at the time of his enlistment or induction a resident thereof". PUB. L. No. 507, 77th Cong., 2d Sess. (March 27, 1942) § 701.

2. As to the maximum period, particularly the inconsistency between the wording of Section 33I and Section 332 (a) of the Nationality Act of I940 (7 years according to $\S 331$; 10 years according to $\$ 332$ (a)) see Hyde, Nationality Act of 1940 (194I) 35 A.x. J. InT. L. 314, 316.

3. Nationality Act of 1940, $\$$ 102 (c), 30I, 331, 54 STAT. II38, I140, II53 (I940), 8 U. S. C. A. \$\$ 502, 701, 73 I (1942). 
addition to what they expressly contain, a prima facie certificate of the holder's eligibility for naturalization.

In contradistinction to the legislation of other countries where naturalization depends in each individual case upon the discretion of the proper governmental agency, it is in this country independent of discretionary interference by administrative authority. In the last resort, it is the Supreme Court of the United States that decides whether American citizenship by naturalization has been duly granted or denied to an applicant. ${ }^{4}$

To be sure, no alien has a vested right to become naturalized, and Congress may, without infringing principles of international law or of the Constitution, change existing naturalization procedure. The change may even be retroactive with the result of excluding from naturalization an alien who theretofore would have been entitled to a certificate of citizenship. ${ }^{5}$ But at present, in the words of the late Justice Brandeis: "There is a statutory right in the alien to submit his petition and evidence to a court, to have the tribunal pass upon them, and, if the requisite facts are established, to receive the certificate. . . In passing upon the application, the court exercises judicial judgment. It does not confer or withhold a favor." 6

Viewed from this juristic perspective, a declarant has a legal claim to naturalization upon fulfillment of specified requirements, subject to certain statutory bars, $e . g$., those enacted with regard to enemy aliens. ${ }^{7}$ There is still another aspect involved in the declaration of intention. The alien makes a solemn assertion that he feels more closely connected with the United States than with his parent country and offers to cast his lot forever with the nation which has granted him hospitality. ${ }^{8}$

Against the practically constant background, just outlined, of that particular feature of American naturalization law, there developed what has been aptly called the "anomalous position" of declarant aliens,

4. This fact was brought before the public by some sensational cases involving conscientious objectors. United States v. Schwimmer, 279 U. S. 644 (I929); United States v. MacIntosh, 283 U. S. 605 (r93I) ; United States v. Bland, 283 UU. S. 636 (I93I). Another set of interesting cases in point is discussed by Hazard, Attachment to the Constitution (I929) 23 AM. J. INT. L. 783 et seq.

5. In re Naturalization of Aliens, I F. (2d) 594, 601 (E. D. Wis. 1924), contains an ingenious distinction by District Judge Geiger between what he calls "sovereign grace" and "judicial grace".

6. Tutun v. United States and Neuberger v. United States, 270 U. S. 568, 578 (1926). See also Hazard, The Right of Appeal in Naturalization Cases (1927) 21 AM. J. INT. L. 40. Section 702 of the Second War Powers Act makes the following exception: "During the present war, any person entitled to naturalization under section 701 of this Act, who while serving honorably in the military or naval forces of the United States is not within the jurisdiction of any court authorized to naturalize aliens, may be naturalized . . without appearing before a naturalization court." PUB. $L$. No. 507,77th Cong., 2d Sess. (March 27, I942) \$ 702. (I942).

7. Nationality Act of 1940, $\$ 326,54$ STAT. II50 (I940), 8 U. S. C. A. $\$ 726$

8. II Hyde, Internattonal Law (ig22) 247. 
namely a status involving some rights and some duties which they do not have in common with other non-citizens, but which they share with citizens.

To be sure, the "alien suffrage" gradually disappeared in one American state after another by way of amendments to their respective constitutions. Arkansas was the last state to abolish it. ${ }^{9}$ Nor are American passports any longer issued to declarants. Now, almost without exception, privileges of a political kind are denied them. ${ }^{10}$ But some statutes, federal and state alike, which normally reserved certain rights and privileges in the economic and professional fields to American citizens, have lifted the bar with regard to declarants as such or to specifically qualified ones. ${ }^{11}$ And, what is most important, resident declarants are subject to military duties to this country, not only in wartime, but, according to recent statutory developments, in peacetime as well. Are they, nevertheless, to be considered as full-fledged aliens? Or, are they nationals, though not citizens of the United States? ${ }^{12}$

9. It was abolished there in 1926. See Aylsworth, The Passing of Alien Suffrage (I93I) 25 AMr. PoL. ScI. REv. II4. For a comprehensive survey of the facts concerning the alien vote as of I885, when it still existed in many American states, see BERNHeim, The History of the LAW of Aliens from the Standpoint of Consparative JURISPRUDENCE (I885) I56 et seq. The issue whether or not the mere right to vote was to be considered identical with acquisition of citizenship was decided in the affirmative in $I n$ re Wehlitz, 16 Wis. 468 (1863); but in the negative in the leading case of Ianz v. Randall, I4 FED. CAS. II3I, No. 8,080 (C. C. D. Minn. I876) and in City of Minneapolis v. Reum, 56 Fed. 576 (C. C. A. 8 th, I893). A recent discussion of this old issue may be found in Petition of Sproule, Ig F. Supp. 995 (S. D. Calif. I937). It must be noted that the declarant, when he was granted a right to vote for the state legislative body, indirectly acquired a share of political influence with regard to the national government as well. In re Wehlitz, supra.

I0. A Pennsylvania alien-registration statute of 1939 exempted, among other categories of aliens, specifically qualified declarants. PA. STAT. ANN. (Purdon, Supp. 1942) tit. 35, § I80I. See Hines v. Davidowitz, 312 U. S. 52 (I94I) where this state law was held unconstitutional on grounds not within the ambit of this article.

II. See the Washington statute concerning the qualification for taking or holding an interest in land in the state of Washington. WASE. REv. STAT. ANN. (Remington, I933) § I0,58I.

For the position of declarant aliens with regard to the right to be engaged in certain professions and trades which normally are not open to aliens, see Chamberlain, Aliens and the Right to Work (1932) I8 A. B. A. J. 379, and Chamberlain, Aliens in the United States, in MacKenzie, The Legar Status of Aliens in Pacific CounTRIES (r937) 33 I.

I2. The distinction between the status of an American citizen, and that of an American national who is not an American citizen, has been "canonized" by Section IOI (b) of the Nationality Act of r940:

"The term 'national of the United States' means (I) a citizen of the United States, or (2) a person who, though not a citizen of the United States, owes permanent allegiance to the United States. It does not include an alien." 54 Srat. Ir37 (1940), 8 U. S. C. A. \$ 50r (1942). But, before the Nationality Act of I940, this bifurcation of the concept of nationality was already recognized by distinguished authorities. REPORT OF THE CITIZENSaIP BOARD (19I7), H. R. Doc. No. 326, 59th Cong., 2d Sess. 207; Coudert, Our New Peoples: Citizens, Subjects, Nationals or Aliens (Ig03) 3 CoL. L. Rev. 13; McGovney, American Citizenship (I9II) II Col. L. Rev. 23I, 326; I HYDE, INTERNATIONAL LAW (I922) 6II; McGovney, Our Non-Citizen Nationals, Who Are They, in RAdIN, LEgAL Essays (I935) 323.

For succinct discussions of the concepts of "Citizen" and of "Nationality" respectively, see Hazard, Citizenship, in VI ENCYCLOPEDIA AMERICANA (194I) 704; Garner, Nationality, in XIX, id. at 765; Flournoy, Nationality, in XI ENCYCLOPEDIA OF THE Soctal Sctences (I933) 249. 
Espousal of the Alien's Claims and Protection of His Person

This is, indeed, the alternative which must be viewed in an attempt at analyzing their legal status. That they are not American citizens is beyond any doubt. But, there is a certain confusion of official language which appears in the fact that the term "citizen" is sometimes used as a synonym for "nationality". This explains, perhaps, the following historical phenomenon. In several conventions which this country concluded at various periods of the last century with other states in order to set up international claims commissions, the various treaties referred, in so far as Americans were concerned, expressly to United States "citizens". Nevertheless, in many instances the American government espoused before such commissions claims of individuals who were, though declarants, not American citizens; or, at least, upon whom this status had not been conferred at the date of the event which gave rise to the claim. More often than not, the particular commission declined jurisdiction. But there are decisions to the contrary on record. It was held, for instance, in the case of Hellman-Sprotto by the United States Mexican Claims Commission, under the convention of July 4, I868, "that a person declaring his intention to become a citizen and keeping his domicile in the United States, is a citizen in the meaning of the convention". ${ }^{13}$

\section{The Koszta Affair}

New historical developments not infrequently revitalize an old international "incident". So with the Koszta affair, which in a noted constitutional case ${ }^{14}$ is referred to as "one of the most remarkable episodes" of American diplomatic history. Its facts are too well known to need recapitulation; ${ }^{15}$ the affair was a striking instance of American naval intervention to rescue a declarant who was kidnapped on neutral territory by agents of the State which he had left as a political refugee. This incident occasioned Secretary of State Marcy's famous note of September $26,1853^{10}$

Though he somewhat overreached himself in his generalizations, especially in his self-styled "doctrine of domicile and consequent na-

I3. Italics supplied. III MOORE, History aND Digest of THE INTERNatToNaI Arbitrations to Which the United States Has Been a Party (I898) 2715. Hereinafter cited Moore, Arbitrations.

14. In re Neagle, I35 U. S. I, 64 (1889).

15. For a succinct summary see I HyDE, INTERNATIONAL LAW (1922) 687, n. 2.

16. For the full text of the Note, see H. R. Exac. Doc. No. I, 33d Cong., Ist Sess. (I853) 30 et seq. It is also reprinted in BRITISE AND Foreign State Papers 1853I854, Vol. 44, pp. 984 et seq. Hereinafter quoted as MARCY's Note with page references to the first mentioned American reprint. It must be noted that the extracts in III MOORE, INTERnational LAW DIGEST (Ig06) 820 et seq., do not cover all the passages upon which emphasis is laid in the following remarks. 
tionality," ${ }^{17} \mathrm{Mr}$. Marcy was a constructive jurist with remarkable vision in the field of international law. Illustrative of his progressive ideas is the note on the Koszta affair. For the purpose it served, this note was necessarily in the nature of an attorney's brief rather than a detached statement. To prove, what was at least pleadable in the case of Koszta, that domicile plus declaration of intention created an American national character, ${ }^{18} \mathrm{Mr}$. Marcy unnecessarily made this sweeping assertion: "It is a maxim of international law that domicile confers a national character." According to him, this rule should be applied in "determining what country has the right to protect" 19 the individual; a statement which was surely untenable de lege lata. ${ }^{20}$

On the other hand, no historical credit has yet been paid, in the existing comments, to one of the juristic highlights of this note: the advancement of the modern distinction between an American citizen and an American national who is not a citizen. The idea of such gradations of nationality, as it were, was the red thread in Mr. Marcy's arguments. As to Koszta's declaration of intention, he did not contend that "this initiatory step in the process of naturalization invested him with all the civil rights of an American citizen; but," he asserted, "it is sufficient for all the purposes of this case to show that he was clothed with American nationality; and, in virtue thereof, the Government of the United States was authorized to extend to him its protection at home and abroad." 21 In this sense must also be understood the passage in President Pierce's first annual message ( 1853 ) where it is maintained, with regard to Koszta, "that at the time of his seizure he was clothed with the nationality of the United States . . . ." 22 So interpreted, Marcy's doctrine anticipated a rather current phenomenon in the field of nationality law. The American nationality which he claimed for Koszta was not that of a citizen, but rather the status of an American noncitizen-national, exemplified presently by the relationship of a Filipino to the United States.

I7. MARCY's Note 43.

18. With this temperamentum, as it were, the doctrine was, in some cases, accepted by the United States Mexican Claims Commission under the convention of July 4 , I868, when Professor Lieber acted as its umpire. See BorChard, Drplomatic ProtecTION OF Citizens Abroad (I915) 574, 575. But even in this modified form, the doctrine was definitely disclaimed by the Department of State in official utterances subsequent to the Koszta case. See, e. g., Secretary of State Bayard's Note of August 5, I885, III MOORE, INTERNational LAW Digest (I906) 847, and Secretary of State Olney's Statement of 1896, referred to in VAN DYNE, Citizenship OF THE UNITED STATES (I904) 75 .

19. The passages quoted are in MARCY's Note 40 ; similar passages, id. at $41,42$.

20. According to the prevailing opinion. See-Cockburn, Nationality (1869) 122, and I HALL, INTERNATIONAL LAW (2d ed. 1890) 208.

21. MaRCY'S Note 40.

22. See II Wharton, Digest of International. Law (2d ed. i887) 359. 


\section{The Piepenbrink Affair}

Another instance of American intervention-this time by diplomatic means-to protect a declarant alien from foreign powers took place during the first World War. August Piepenbrink, a German citizen with American "first papers" and a steward on the American vessel Windsor, was removed therefrom by a French navy detachment, to be held as prisoner of war by the British in Kingston, Jamaica. The American government undertook formal steps toward his release. The amicable settlement which eventually closed the affair gave full satisfaction to the American demand and set the prisoner at liberty; however, it did not contain any acknowledgment whatever of the legal contentions which formed the basis for the American claim. ${ }^{23}$ Mention must be made, in this connection, of the fact that Piepenbrink's special status was not the only point at issue. The American government also maintained that his removal from a neutral ship constituted a violation of international law regardless of his particular relationship to this country. In this respect, Great Britain's position in the famous Trent affair (during the Civil War period) was now adopted by the United States. ${ }^{24}$ Nevertheless, this government's first assertion was that Piepenbrink should be treated substantially as an American national. Reference was made to the following provisions of a domestic statute:

"That every seaman, being an alien, shall, after his declaration of intention to become a citizen of the United States and after he shall have served three years upon such merchant or fishing vessels of the United States, be deemed a citizen of the United States for the purpose of serving on board of any such merchant or fishing vessel of the United States, anything to the contrary in any Act of Congress notwithstanding; but such seaman shall, for all purposes of protection as an American citizen, be deemed such after the filing of his declaration of intention to become such citizen." 25

Considerations of space preclude us from discussing the general question of whether, in the absence of any declaration of intention, alien seamen serving on board a national vessel are under the protection of the flag state according to customary international law. ${ }^{20}$ For our pres-

23. For the diplomatic correspondence concerning the Piepenbrink affair, see (1915) Am. J. Int. L. (Spec. Supp.) 355 et seq.

24. The same issue appeared in the present war and was, between Great Britain and Japan, discussed with regard to the "Asama Maru" incident.

25. REv. Stat. § 2174 (I875), as amended, 40 Stat. 544 (I9I8). Italics supplied. This provision can be traced back to a substantially identical one contained in the Act of June 7,1872 , which is discussed in Van Dyne, Citrzenseip of the UnIted States (1904) 75. Cf. the Richelieu case, id. at 76 .

26. In re Ross, I40 U. S. 453, 472 (I89o), though mostly referred to in the present connection, is, we believe, not in point. This case does not deal with the problem of 
ent purposes, it is sufficient to point out that, under the above-quoted statute, only the additional fact of possessing his "first papers" gave an alien seaman employed on an American vessel the possibility of invoking this country's protection. This statutory provision was repealed in I935. ${ }^{27}$ However, its exact juridical bearing had been determined before then in the famous case of Hilson v. Germany. ${ }^{28}$

\section{The Hilson Case}

Edward A. Hilson was a radio operator on the American steamship Columbian when she was stopped and sunk by a German submarine in November, I9I6. Hilson was a British subject, at the time, with American "first papers". Only afterwards did he complete his naturalization; but he was already an American citizen when his claim for damages because of injuries and lost property came to be espoused by the American Government before the Mixed Claims Commission. This agency was established by the American-German agreement of August IO, I922, subsequent to the Treaty of Berlin of August 25, 1921. The Commission had previously set forth the prerequisites for making a claim on behalf of an American national. Contained in Administrative Decision $V$, October $3 \mathrm{I}$, I924, was the following rule: "The term 'American national' means a person wheresoever domiciled owing permanent allegiance to the United States of America, and embraces not only citizens of the United States, but Indians and members of other aboriginal tribes or native peoples of the United States and of its territories and possessions."

In pressing Hilson's claim, the American commissioner asserted in effect that the applicable statute squared with customary international law ${ }^{29}$ to this the German commissioner objected. Denying the claim, particularly its assertion of American nationality, Judge Parker, the

protection, but rather with the jurisdictional aspect of the situation arising in the contingency of penal offences committed by aliens on board ships on the high seas.

But in the old case, McCready v. Mexico, submitted to the Claims Commission under the convention of July 4, I868, umpire Thornton made the well-known pronouncement that "seamen serving in the naval or mercantile marine under a flag not their own are entitled, for the duration of that service, to the protection of the flag under which they serve". III'MOORE, InTERnational IAw DIGEST (Ig06) 795, and III Moore, Arbitrations, 2536, 2537. For a similar dictum, see the English case, The Leon XIII, 5 Asp. Mar. Rep. 25, 26 (I882).

27. Act of June I5, I935, 49 STAT. 376, 8 U. S. C. A. \$376n. (I942). The idea was one belonging to the field of labor policy, namely: to exclude so-called "three-year certificate men" from that quota of the crew of certain vessels which has, under the Merchant Marine Act of I928 and similar statutes, to consist of American citizens. 79 CoNG. ReC. I438, 1439, 897I (1935). The repealing statute, by operating on that part of the section relative to protection as well as that relating to qualification for service, overreached this purpose in our opinion.

28. See Mixed Claims Commission, United States and Germany, Administrative Decisions and Opinions to June 30, I925 (Docket No. 26, February 2I, 1925) 231 et seq.

29. Id. at 233, 234. 
Commission umpire, stressed the fact that Hilson became an American citizen after the incident from which his claim arose; thus, he could not be considered an American national within the rule of Administrative Decision V. Referring to "permanent allegiance" as the basis of the nationality conception, Judge Parker maintained that Hilson owed to the United States only a temporary allegiance, limited to the duration of his service on an American ship. According to the umpire, "It has never been held that the mere declaration of intention to become an American citizen constituted a tie permanently binding the declarant to the United States". In his analysis of Section 2174, Judge Parker concluded that this provision of domestic scope extended protection to an individual in Hilson's position "not as an American national, but as an alien seaman". ${ }^{30}$

Judge Parker's theory in the Hilson case represents in a sense the anticlimax to Secretary of State Marcy's plea in the Koszta affair. Both were fully aware of the conceptual difference between the status of an American citizen and an American national. But whereas $\mathrm{Mr}$. Marcy substantially ascribed to resident declarants the position of noncitizen-nationals of the United States, this status was denied them by Judge Parker. Abandoning Mr. Marcy's doctrine, the Department of State has adopted a policy consonant with Judge Parker's opinion in the Hilson case. In its "General Instructions for Claimants" appears this passage:

"Nationality of Claim. The Government of the United States can interpose effectively through diplomatic channels only on behalf of itself, or of claimants (I) who have American nationality (such as citizens of the United States, including companies and corporations, Indians, and members of other aboriginal tribes, or natives of the United States or its territories or possessions, etc.), or (2) who are otherwise entitled to American protection in certain cases (such as certain classes of seamen on American vessels, members of the military or naval forces of the United States, etc.) . . . the declaration of intention to become a citizen of the United States is insufficient to establish the right to protection by the United States except in case of American seamen." 31

This official policy of the American Government is in complete accord with the classic principles of diplomatic protection. ${ }^{32}$ Demon-

30. Id. at 237 , n. I, 239,240 , n. 5 .

3r. Italics supplied. Reprinted in Ralston, The Law and Procedure of InterNationat. TRIBUNALS (I926) 440.

32. Borchard, Diplomatic Protection of Citizens Abroad (1915) 572 . For a different, but not convincing opinion, see Wolfmann, Status of a Foreigner Who Has Declared His Intention of Becoming a Citizen of the United States (1907) $4 \mathrm{I}$ AM. L. REv. 498, 499, 500. 
strative of the malleability of the whole protection practice, exceptions $^{33}$ to the normal rule do not challenge the principle. Such irregularities appear in the obverse where diplomatic protection, normally the token of nationality, is, for cause, refused to American citizens. ${ }^{34}$

It follows as a corollary to the principle propounded by Judge Parker and adopted by the Department of State that a declarant alien remains under the protection of his parent state so long as he does not lose its nationality. ${ }^{35}$ This is incompatible with the Marcy doctrine that the status of an American noncitizen-national may be ascribed to a resident declarant. Legislation designed to delineate an intermediate status between citizenship and full-fledged alienage for resident declarants has been proposed. Conceivably, such a definitive enactment might mollify international difficulties arising out of the "double-nationality" 36 situation in which both the parent State and the adopted State assert a right of protection over the individual. ${ }^{37}$ More important, in this respect, is the issue concerning the lawfulness, internationally, of subjecting resident aliens to compulsory military service.

\section{Military Conscription of Declarants}

Both during the Civil War and World War I, able-bodied male declarants were made liable for service with the armed forces of the United States. In both instances a certain avenue for withdrawing from this legal duty was opened by amendments enacted under pressure of foreign diplomatic representations. During the Civil War period the military liability of duly qualified declarants was first unconditionally established. But by President Lincoln's proclamation of May 8,

33. For instance, in the Bishop case (March 5, 1925, Docket No. 596) and in the Harrison case (March II, 1925, Docket No. 220I), Mixed Claims Commission, United States and Germany, Administrative Decisions and Opinions to June $30,1925,577,586$, this country espoused, if unsuccessfully, claims associated with declarants who were not seamen on American vessels.

34. Jessup, Revising Our Nationality Law (1934) 28 Ax. J. INT. L. 104, I07, says: ". . protection may always be extended or withheld at the discretion of the Secretary of State. ..."

35. A collective denationalization of emigrated German Jews has been announced by the Eleventh Decree for the Execution of the Reich Citizen Law, November 25, I94I, I ReichisgesetzBL.ATT (Nov. 26, 194I). An English translation of this novel Nazi decree is contained in (I942) 5 CONTEMPORARY JEWISH RecordS 202.

Cf. The diplomatic correspondence between the United States and Italy concerning certain lynching cases. Some of the Italians who fell victim to these lynching incidents were resident declarants. III MOORE, InTERnational LaW Digest (Ig06) 344 .

36. Borchard, Diplomatic Protection of Citizens Abroad (igi5) 588 ; Art. 4 of the Hague Convention on Nationality Laws (1930) 24 AM. J. INT. L. (Special Supp.) 193.

37. A bill with a scheme for the creation of "an intermediate status" of "noncitizen-national of the United States" for aliens permanently residing in this country was introduced by Congressman Gearhart on July II, 1940, and later died in Committee. H. R. 10,202, 76th Cong., 3d Sess. (1940). 
I863, they were allowed to retire from this obligation by leaving the country within sixty-five days.

In the World War the Selective Draft Law of May I8, I9I7, which imposed a liability to military service upon male declarants of a certain specified age who were "not alien enemies", was amended by an Act of Congress of July 9, x9r8. This amendment substantially provided that a declarant of neutral nationality, subject under the statute to military service, should be relieved therefrom upon cancelling his declaration of intention to become an American citizen. This was supposed to have the further effect of debarring him forever from becoming naturalized in this country. A similar provision was embodied in the amended Selective Draft Act of August 31, I9I8.38

As compared with these earlier statutes, the inclusion of resident male declarants between certain ages among the persons liable, under Section 3 of the Burke-Wadsworth Act, ${ }^{39}$ for training and service in the land and naval forces of the United States amounts to a novelty in kind, and not only in degree. First, because of the permanent character of this legislation, which it has in common with some previous militia laws; ${ }^{40}$ second, and more important, because it transcends in its scope the compass of a mere emergency call. The liability for training and service under the Burke-Wadsworth Act, even though this enactment was occasioned by an acute crisis on the international scene, belongs to the normal relation between this country and certain individuals, included within the statute's provisions. The corresponding right to require the fulfillment of this duty is not an incident of war-time government, but of peace-time government as well. Persons upon whom the liability is incumbent are called upon not only when the necessity of national defense has become actual or imminent, but at regular intervals for the permanent purpose of securing a stock of militarily trained man-power.

Under Section 3 in its original form the draft liability extended, apart from citizens, to resident male declarants between the ages of twenty-one and thirty-six. No exemption was provided for enemy aliens, in spite of well-founded objections to this omission, raised dur-

38. But, during the Spanish-American War of 1898 , able-bodied male declarants between the ages of 18 and 45 were made liable to military service in the American national forces without being given the possibility of withdrawing from such duty in a legally prescribed way. 30 STAT. 36I (1898), Io U. S. C. A. \& I (1934).

39. 54 Stat. 885 (1940), 50 U. S. C. A. $\$ 307$ (Supp. I94I), as amended, PUb. L. No. 360,77 th Cong., Ist Sess. (Dec. 20, 194I) $\$ 3$ (a).

40. 30 Stat. 36r (1898), io U. S. C. A. § I (1934), referred to in II Hyde, INTERNATIONAL LAW (I922) §626, n. 4, and 39 STAT. 197 (I9I6), 32 U. S. C. A. § I (I934), mentioned in III Willoughby, The Constirutional Law of the United States (2d ed. I929) I55I, n. 45. 
ing the hearings on the bill.41 In contrast with the Civil War and World War precedents, no possibility for a declarant's withdrawing from this duty was opened, at least not expressly.

Under pressure of representations made by Mexico and other foreign governments, Secretary of State Hull advised the alteration of this statute in a letter to Representative Rayburn, Speaker of the House of Representatives. ${ }^{42}$ An amendment enacted on December 20, I94I, changing the age limits for draft eligibles, included these important provisos:

"Provided, That any citizen or subject of a neutral country shall be relieved from liability for training and service under this Act if, prior to his induction into the land or naval forces, he has made application to be relieved from such liability in the manner prescribed by law . . . but any person who makes such application shall thereafter be debarred from becoming a citizen of the United States.

"Provided, That no citizen or subject of any country who has been or may hereafter be proclaimed by the President to be an alien enemy of the United States, shall be inducted for training and service under this Act unless he is acceptable to the land or naval forces." 13

The amended act extended the-draft liability from citizens and resident male declarants to "every male citizen of the United States, and every other male person residing in the United States." It thus eliminated the most striking difference between the legal position of a resident declarant and another resident alien.44

The exemptions established under this amendment are dealt with as "Class IV-C" in the Selective Service Regulations." These regulations lay the burden of proving alien status on the registrant claim-

41. Hearings before the Committee on Military Affairs on H. R. ro,132, 76th Cong., 3d Sess. (1940) 594, 595.

42. The N. Y. Times, April I7, 1940, p. I4, cols. $4,5$.

43. 54 Stat. 885, 50 U. S. C. A. $\$ 307$.(Supp. I94I).

44. It may be noted that the conscription law of the Confederate States embraced all white men of certain ages who were "residents of the Confederate States". Ex parte Samuel Blumer, 27 Texas 734,736 (1865).. "To require the military service of domiciled foreigners, is an undoubted and recognized right." Ex parte Samuel Blumer, supra.

See also Art 180 of the Dutch constitution which reads: "All citizens of the Netherlands who are able to do so are obliged to assist in maintaining the independence of the kingdom and in defending the territory. This obligation may also be imposed upon residents who are not citieens". (Italics supplied.) II Dopn, Moder ConstrtuTION (I909) II5, and WIJTHOFF, DE STAATSINRICHIING VAN NEDERLAND (3d ed. 1935) 406.

A similar provision was already contained in Art. 8 of the famous Union of Utrecht (January 29,1579 ). That there is a substantial difference in status between a resident alien (ingezetenen) and any other alien (vremdelingen) is thus a time honored rule of Dutch law.

45. Part 622, § 622.43. 
ing release on such ground. ${ }^{40}$ According to the prescribed rules, the "Application by Alien for Relief from Military Service" (Form 30r) shall be disregarded "if registrant is a national of the United States but also contends that he is a citizen or subject of a neutral country or an alien enemy".

Between the amended Selective Service Act ${ }^{47}$ and the abortive Senate Bill, S. I397, which it supplanted, significant differences are to be observed. Introduced on April 25, I941, at the State Department's insistence ${ }^{48}$ by Senator Reynolds, it purported to be "a bill to provide for the exemption from military service of certain aliens residing in the United States".

The Senate proposal retained the traditional distinction, with regard to compulsory military service, between resident declarants and other resident aliens. In the original Selective Service Act only such aliens who had declared their intention to become American citizens were subject to conscription; this provision was embodied in S. I397. But under the new amendment, "every male citizen of the United States and every other male person residing in the United States" is classified as a military eligible; thus, every resident noncitizen, irrespective of any declaration of intention, may be inducted into the military forces. ${ }^{49}$

In the Senate bill was an escape clause, permitting application for relief from military service even after the alien has been inducted into the army, provided his application was made "within a time fixed by the President". Under the amended Act, however, in order to be effectual the applicant's petition must be presented before his induction. ${ }^{50}$

46. Corresponding to the judicial practice developed by the federal courts in cases which arose from the World War I draft. Cf. II HYDE, INTERNATIONAL LAW (1922) 254, n. 3 .

47. 54 Stat. 885, 50 U. S. C. A. § 307 (Supp. I94I).

48. See Sen. Rep. No. 394, 77th Cong., Ist Sess. (I94I) 3, 4.

49. Consequently, the following are categories of persons who, while not American citizens, but nevertheless resident in this country, are now subject to the draft obligation: such American nationals who are ineligible for American citizenship and consequently not admitted to a declaration of intention; such fullfiedged aliens who are, on account of their race or for other reasons, ineligible for American citizenship; such fullfledged aliens who are exempted, under the naturalization law, from the requirement of a declaration of intention and were obviously overlooked when the original Selective Training and Service Act came to be drafted; finally and most important, those fullfledged aliens who, though eligible for citizenship, preferred not to make a declaration of intention. See also: Graham, Are Latin American Students Subject to the Draft? (1942) Io GEO. WASH. L. REV. 845 .

There remains, however, the fact that according to Section 5 (a), as amended in December, I94I, the President's discretionary authority to specify categories of persons to be relieved from liability for training and service extends only to such resident non-citizens who have not made a declaration of intention. See H. R. REP. No. 1508, 77th Cong., Ist Sess. (194I) 4.

50. The rationale for the more liberal standpoint recommended by the Department of State was indicated by Capt. Francis V. Keesling, Jr. Hearings before Committee on Military Affairs on S. 2126, 77 th Cong., Ist Sess. (194I) 46. 
In its escape clause, the Senate bill suggested no different treatment for enemy aliens as distinguished from other alien draftees. But under the law as enacted, the application to be relieved from the liability for training and service can be made only by a "citizen or subject of a neutral country".51 The situation of an enemy alien is covered by a special provision. His induction into military service lies entirely within the discretion of proper military authorities, for the act stipulates that any such alien may be inducted if "he is acceptable to the land or naval forces." 52

Possibly, this provision might be construed as conflicting with Article $23(h)$ of the Hague Regulations concerning the Laws and Customs of War on Land which forbids "a belligerent to compel the nationals of the hostile party to take part in the operations of war directed against their own country, even if they were in the belligerent's service before the commencement of the war". ${ }^{53}$ Whether this prohibition is applicable to an individual who possesses the nationality of both countries is an unresolved question. The Italian War Law of I938 answers in the negative. ${ }^{54}$ As to the normal contingency of single nationality, Article 23 (h) may cause some difficulty in its practical application to so-called "friendly enemy aliens".55 And a further question may be raised: whether the mere induction of an enemy alien into military service makes him, in terms of the Hague Convention, a participant "in the operations of war" directed against his own country. ${ }^{56}$

Two sorts of diplomatic objections to the drafting of resident declarants had been mentioned in the State Department's letter to Senator Reynolds, ${ }^{57}$ chairman of the Military Affairs Committee: Mexico

5I. Pub. L. No. 360, 77th Cong., Ist Sess. (Dec. 20, I94I) $\$ 3$ (a).

52. Ibid.

53. Farther than the wording of Art. 23 (h) Hague Regulations, but probably not farther than its purpose, goes this statement, made by a delegate of the Judge Advocate General of the Navy: "Every modern authority on international law holds without exception that alien enemies may not be forced to serve in the armed forces of a belligerent." (Italics supplied.) Hearings before Committee on Military Affairs on H. R. 10,132, 76th Cong., 3d Sess. (1940) 595 .

54. Art. 37 of the Legge di Guerra, concerning the prohibition to compel enemy subjects to participate in "belligerent actions" (azioni di guerra) against their country, contains the following passage: ". . . the provision of the foregoing paragraph does not apply to enemy subjects who at the same time possess the Italian nationality. ..." (Author's translation.) See XVI Raccolta UfFictale Delie LegG I Decretr (I938) 2478,2482 .

Article I of the Protocol concerning military obligations in certain cases of double nationality, concluded at the Hague Conference on April 12, 1930, is, we submit, not in point. It does not, we believe, cover the particular contingency of a state of war between the two or more countries whose nationality a given individual possesses simultaneously.

55. Captain Keesling pointed out that "there are a number of people who are technically enemy aliens but who actually are just aching to get at the country of which they are nationals and of which they happen to be the minority groups". Hearings before Committee on Military Affairs on S. 2126, 77th Cong., Ist Sess. (194I) 49.

56. See note 53 supra.

57. See note 48 supra. 
grounded its complaint upon alleged principles of international law; Germany, Spain and Switzerland based their representations on existing treaty obligations of the United States.

Commenting on Mexico's objection, the Department of State conceded that the American government itself had "indeed on numerous occasions in the past . . objected to the compulsory military service of its nationals in the armed forces of foreign states, even in the absence of treaty provisions guaranteeing such exemptions." 58 Secretaries of State Madison and Seward are on record with statements to this effect, ${ }^{59}$ while on September 26, I9I7, Secretary of State Lansing admitted "the principle of international law preventing the compulsory drafting of neutral aliens", except "if the Nation is called upon to resist an invasion". ${ }^{60}$ The American World War practice of conscripting resident declarants found the approval of a distinguished authority, ${ }^{61}$ but its validity has never been established by a decision of the Supreme Court. ${ }^{62}$

European legislators have not so far provided for the compulsory military service of resident aliens, except for individuals without nationality and "quasi-stateless" persons. Writers on international law mostly deny the lawfulness of subjecting nationals of a foreign

58. The United States made, however, a "reservation" to Article 3 of the Habana Convention on the Status of Aliens (ig28) which reads:

"Foreigners may not be obliged to perform military service; but those foreigners who are domiciled, unless they prefer to leave the country, may be compelled, under the same conditions as nationals, to perform police, fire-protection or militia duty for the protection of the place of their domicile against natural catastrophes or dangers not resulting from war." (1928) 22 AM. J. INT. L., Official Documents 137.

The Hague Conference for the Codification of International Law (I930) did, apart from the Protocol relating to military obligations in certain cases of double nationality, not deal with the problem of compulsory military service of resident aliens. But the International Conference on Treatment of Foreigners, held at Paris, November 5th-December 5th, I929, proposed the conclusion of a multilateral convention to the effect that the nationals of each of the contracting Parties "shall also be exempt in the territory of the other High Contracting Parties, in peace time and in war time, from all compulsory military service, whether in the army, navy or air forces, or in the national guard or militia, and from all compulsory services in connection with national defense. - " League of Nations Document, C. 97, M.23 (1930) 441, 523. This proposal was never carried out.

59. IV MOORE, INTERNational LAw Digest (1906) 52, 53.

60. Hearings before Committee on Military Affairs, House of Representatives on S. J. Res. 84,65 th Cong., Ist Sess. (I9I7) 4 , Io.

6I. II Hyde, International Law (1922) 244, 246, 247. Comment thereon in Gibbons, The Selective Service Acts of 1917 and 1940 (I94I) 9 GEO. WASH. L. REv. 687,689 , n. 18. Cf. also the unsigned Comment, Aliens under the Selective Draft Act (I917-1918) 27 YAle L. J. 683; Edmunds, Aliens and the Draft (1920) 5 ST. Louis L. Rev. 23; III Willoughig, The Constitutional LAw of the United STATES (2d ed. 1929) 1556, 1557; Mickelwait, Legal Basis for Conscription (1940) 26 A. B. A. J. 701, 704.

See also Fitzhugh and Hyde, The Drafting of Neutral Aliens by the United States (1942) 36 AM. J. InT. L. 360 .

62. The opinion in Selective Draft Law Cases, 245 U. S. 366 (1918) does not touch upon this particular problem even though it speaks of the "reciprocal obligation of the citizen to render military service". Id. at 378 .

But, an acrimonious criticism of the drafting of declarants was voiced by a lower court in In re Siem, 284 Fed. 868, 870 (D. Mont. 1922). 
country to military conscription. ${ }^{63}$ But this is sometimes qualified with regard to "enrollment for police purposes and local protection, especially in times of sudden emergency". ${ }^{64}$

De lege ferenda, it may be mentioned that about twenty years ago a noted scholar submitted the revolutionary suggestion of supplanting "the outworn conception of allegiance" by a status of being "permanently settled" in a country "with no definite intention of departing therefrom"; a test which should be applied, according to him, also with regard to "whom the state may force into its armies". ${ }^{65}$

The complaints against conscription of "treaty nationals", exempted from military service by various bilateral conventions, ${ }^{66}$ are grounded primarily upon two types of clauses which occur in United States treaties. ${ }^{67}$ The older one which, in varying language, appears as late as $1920,{ }^{68}$ substantially enjoins that "the citizens or subjects of each of the High Contracting Parties shall be exempt in the territories of the other from all compulsory military service, by land or by sea . . ." 69 The more modern clause, adopted for the first time in Article 6 of the treaty of commerce with Germany, December 8, I923, posits a marked distinction between resident declarants and other treaty nationals. It has the following stereotyped text:

"In the event of war between either high contracting party and a third State, such party may draft for compulsory military service nationals of the other having a permanent residence within its territories and who have formally, according to its laws, declared an intention to adopt its nationality by naturalization, unless such individuals depart from the territories of said belligerent party within sixty days after a declaration of war." 70

63. See, e.g., I Otpenheim, International Law (Lauterpacht's 5th ed. I937) $237,238$.

64. Borchard, Diplomatic Protection of Citizens Abroad (igi5) 65, 66.

65. Baty, The Interconnection of Nationality and Domicile, in WIGMIORE, CeneBRATED LEGAL ESSAYS (I919) I87, I97, I98, reprinted in (I918-19I9) I3 ILL. L. REV. $363,373,374$. See also Baty, The Canons of International Law (1930) 367.

66. Their conclusion was recommended by the third voen of the Hague Peace Conference of 1907.

67. Apart from the obviously obsolete convention, "providing for reciprocal military service", which were, in I9I8, concluded with the then allied Governments of France, Great Britain, Greece, and Italy respectively.

68. Examples: Art. V of the Treaty with Spain (I902), II Malloy, Treatres, Conventions, etc., Between the United States and Other Powers (19io) I703; and Art. I of the Treaty with Siam (1920), U. S. Treaty Series, No. 655.

69. Language in Art. V of the Treaty with Spain, note 68 supra.

70. (1926) 20. AMr. J. INr. L. (OFF. Doc.) 7. The same clause is contained in Art. 6 of the treaties of commerce with (in chronological order): Hungary (June 24 , 1925), Salvador (February 22, I926), Honduras (December 7, I927), Latvia (April 20, 1928), Norway (June 5, 1928), Austria (June 19, 1928).

According to the letter of the Department of State, note 48 supra, Germany construed the treaty to mean that neither party has a right to draft declarants unless it is at war, and the Department of State added : "Such a consruction is probably justified." 
The method suggested by the State Departmient and substantially adopted by the amended Act, intended to parry critical thrusts directed at American practices by other governments, does not distinguish "treaty nationals" from other aliens; nor is there an attempt to categorize separately such nationals according to provisions of the treaties with their respective countries. The drafted citizen of a neutral country upon application is given a certain possibility of being relieved from his liability for training and service. The underlying philosophy seems to be that in his not filing an application there is implied an expression of his will to serve voluntarily in this country's armed forces, a "constructive enlistment," as it were. ${ }^{71}$ Whether this is conclusive and whether it is likely to allay foreign resentment against the earlier statute, it is impossible to consider within the limits of this discussion. It is sufficient to suggest that the number of persons over whom bona fide international controversies could arise would be considerably reduced by an American law creating the possibility of an intermediate status of noncitizen-national of the United States for a resident declarant.

\section{ConcLusion}

As to this country, an individual who has made a declaration of intention to become a citizen under the naturalization law remains, normally, a full-fledged alien, irrespective of his residence. It may plausibly be maintained that declarants enrolled in the armed forces are, for the duration of their service, noncitizen-nationals. ${ }^{72}$ But this possible variation from the normal status of alienage is open to contention.

With due regard to the international limits of the domestic domain (domaine réservé) in questions of nationality law, it is the receiving country alone which has the final determination of an immigrant's admission to the status of a national. That the American law does not single out declarants, or resident declarants, as vested with a legal standing different from full-fledged alienage, is established beyond doubt by the enemy alien status ascribed to them in the event that the country of their origin becomes a belligerent against the United States. ${ }^{73}$

7r. A theory of "constructive enlistment" was, on another occasion, expounded in an opinion of the Judge Advocate General (June 2I, IgI8). ScHILler, MrLITARY LAw AND DEFENSE LEGISL.ATION (I94I) I08.

72. See Prince Elie de Bourbon, Cour de Cassation, May I4, I923, (1923) I DaLLoz, JURISPRUdence, I08, and the award of the Permanent Court of Arbitration at The Hague (May 22, I909) concerning the Casablanca incident between France and Germany. (1909) 3 AM. J. INT. L. 755.

73. Section 326 of the Nationality Act of I940, 54 STAT. II5O (I940), 8 U. S. C. A. $\$ 726$ (Ig42). Regarding the previous law, see Ex parte Graber, 247 Fed. 882 (N. D. Ala. (918). 
As the law now stands, not the declaration of intention coupled with American residence, but rather the mere circumstance of residence in the United States is the fact which generates an alien's duties under the Selective Training and Service Act. As for the wider relation between an alien and the country in which he is settled, before consummation of the naturalization process it amounts to no more than a temporary, as distinguished from so-called permanent allegiance. ${ }^{74}$ This seems to be the almost unanimously accepted theory. A decision of the British Privy Council which went a long way in the opposite direction has been ingeniously discredited by a noted scholar. ${ }^{75}$

Whether the present law should be revised to create an intermediate status of noncitizen-national ${ }^{76}$ for resident declarants is a question which deserves serious consideration. ${ }^{77}$

The beneficiary of such a legal reform would be this country. Bona fide foreign protests against the drafting of foreign citizens or nationals would be obviated if these individuals were, under United States law, nationals of this country. For according to the r93o Hague Conference Protocol concerning military obligations in certain cases of double nationality, "a person possessing two or more nationalities who habitually resides in one of the countries whose nationality he possesses and who is in fact most closely connected with that country, shall be exempt from all military obligations in the other country or countries." 78 Thus, as to his military obligations, the country of the individual's residence prevails over the country to which he only technically belongs. The provisions of this multilateral treaty, though primarily conventional international law, are generally understood as being declarative of customary international law as well. Under this assumption, the conscription of resident declarants would be immune against justified diplomatic protest if they were American nationals, though not American citizens.

Further, with the creation of this intermediate status the United States would be privileged under international law to exercise diplomatic protection over resident declarants, except as against any country to which they have an equal claim of nationality. Whether this privilege is to be utilized lies within the discretion of the Department of State;

74. Even though "temporary allegiance", as a technical term for the tie between a state and its nationals, nowadays does not mean that this tie cannot be severed, but rather "that so long as it continues it exists whether the national is for the moment in the territory of the state or abroad". I WESTLAKE, INTERNATIONAL LAW (2d ed. I9Io) 206. Cf. Carlisle v. United States, I6 Wall. 147, I54 (U. S. 1872).

75. Baty's note in (I908) 33 The Law Magazine and Review 214, critically discussing the decision in De Jager v. Attorney General of Natal, [Ig07] A. C. 326.

76 . One of the conditions should consist of the willingness of the applicant to renounce his foreign allegiance, if he possesses any, simultaneously with the acquisition of the intermediate status.

77. See the bill H. R. 10,202, mentioned in note 37 supra.

78. See note 54 supra. 
for, even as to citizens the privilege is not a duty under international or domestic law. Reverting to antiquity, it is to be noted that in Athens the metoecs (resident aliens), while on the one hand liable to compulsory military service, were, on the other hand placed under the official protection of the Athenian people. ${ }^{78}$

To the resident declarant would accrue the benefit of diplomatic protection, though he would remain excluded from the rights and privileges inherent in American citizenship. He would enjoy the great moral advantage of legally belonging to the national community with which he has factually cast his lot; and the immigrant's "man without a country" feeling, especially generic to political refugees, would be largely dissipated.

In President Cleveland's annual message of 1885 he wrote: "The rights which spring from domicile in the United States, especially when coupled with a declaration of intention to become a citizen, are worthy of definition by statute. The stranger coming hither with intent to remain, establishing his residence in our midst, contributing to the general welfare, and by his voluntary act declaring his purpose to assume the responsibilities of citizenship, thereby gains an inchoate status which legislation may properly define." 80

79. I Phillipson, The International Law and Custom of Anctent Greece AND ROME (IgII) I68, 172.

80. VIII Richardson, a Compilation of the Messages and Papers of the Presidents I798-I897 (1898) 336. 